\title{
Status of insecticide resistance and its biochemical and molecular mechanisms in Anopheles stephensi (Diptera: Culicidae) from Afghanistan
}

Noor Halim Zahid Safi' , Abdul Ali Ahmadi', Sami Nahzat ${ }^{1}$, Supriya Warusavithana' ${ }^{2}$ Naimullah Safi Reza Valadan ${ }^{3,4}$, Atie Shemshadian ${ }^{5}$, Marzieh Sharifi ${ }^{4}$, Ahmadali Enayati ${ }^{5^{*}}$ (D) and Janet Hemingway ${ }^{6}$

\begin{abstract}
Background: Insecticide resistance of Anopheles stephensi, the main malaria vector in eastern Afghanistan, has been reported previously. This study describes the biochemical and molecular mechanisms of resistance to facilitate effective vector control and insecticide resistance management.

Methods: Mosquito larvae were collected from the provinces of Kunar, Laghman and Nangarhar from 2014 to 2017. The susceptibility of the reared $3-4$ days old adults was tested with deltamethrin $0.05 \%$, bendiocarb $0.1 \%$, malathion $5 \%$, permethrin $0.75 \%$ and DDT 4\%. Cytochrome P450 content and general esterase, glutathione S-transferase (GST) and acetylcholinesterase (AChE) activities were measured in the three field populations and the results were compared with those of the laboratory susceptible An. stephensi Beech strain. Two separate allele-specific PCR assays were used to identify L1014, L1014F and L1014S mutations in the voltage gated sodium channel gene of An. stephensi. Probit analysis, ANOVA and Hardy-Weinberg equilibrium were used to analyse bioassay, biochemical assay and gene frequency data respectively.

Results: The population of An. stephensi from Kunar was susceptible to bendiocarb, apart from this, all populations were resistant to all the other insecticides tested. The differences between all values for cytochrome P450s, general esterases, GSTs and AChE inhibition rates in the Kunar, Laghman and Nangarhar populations were statistically significant when compared to the Beech strain, excluding GST activities between Kunar and Beech due to the high standard deviation in Kunar. The three different sodium channel alleles [L1014 (wild type), L1014F (kdrwest) and L1014S (kdr east)] were all segregated in the Afghan populations. The frequencies of kdr east mutation were $22.9 \%, 32.7 \%$ and $35 \%$ in Kunar, Laghman and Nangarhar populations respectively. Kdr west was at the lowest frequency of $4.44 \%$.

Conclusions: Resistance to different groups of insecticides in the field populations of An. stephensi from Kunar, Laghman and Nangarhar Provinces of Afghanistan is caused by a range of metabolic and site insensitivity mechanisms, including esterases, cytochrome P450s and GSTs combined with AChE and sodium channel target site insensitivity. The intensity and frequency of these mechanisms are increasing in these populations, calling for urgent reorientation of vector control programmes and implementation of insecticide resistance management strategies.
\end{abstract}

Keywords: Anopheles stephensi, Insecticide resistance, Metabolism, kdr

\footnotetext{
*Correspondence: ahmadali_enayati@yahoo.com; aenayati@mazums.ac.ir

${ }^{5}$ Department of Medical Entomology and Vector Control, School

of Public Health and Health Sciences Research Centre, Mazandaran

University of Medical Sciences, Sari, Iran

Full list of author information is available at the end of the article
} 


\section{Background}

Malaria is a major endemic vector borne disease in Afghanistan. The 2018 World Malaria Report states that 27,50 and $23 \%$ of the total population of $35,530,083$ Afghans are at high, low and no risk of malaria, respectively [1]. Although there are 6 potential malaria vector species, Anopheles stephensi is the major vector in the eastern provinces of Kunar, Laghman and Nangarhar [2-4]. This species is common in the Middle East and the Indian subcontinent extending to South China and Myanmar [5].

In Afghanistan, the malaria control is reliant on indoor residual spraying (IRS) with deltamethrin, or more recently bendiocarb, combined with distribution of LNs mostly PermaNet [6, 7]. During 2007-2016 over 2 million deltamethrin-treated LNs were distributed in Kunar, Laghman and Nangarhar [6], with a top up distribution of 45,000 LNs in Kunar and Laghman Provinces in 2017 [6].

Insecticide resistance in An. stephensi to all four classes of insecticides including DDT, malathion, bendiocarb, permethrin and deltamethrin in Kunar, Laghman and Nangarhar Provinces has been reported, although it remained susceptible to bendiocarb until 2014 in Afghanistan $[8,9]$. Resistance to DDT, dieldrin, malathion and more recently pyrethroids has also been reported in $A n$. stephensi from the Middle East and the Indian subcontinent [6, 9-16]. Selection of resistance to bendiocarb in An. stephensi was recently reported from Afghanistan [6].

Several mechanisms, including metabolic resistance and site insensitivity can cause insecticide resistance [12, 15, 17-27]. In a previous study on An. stephensi from Afghanistan, general esterases (GES), glutathione $S$-transferases (GSTs), cytochrome P450s and insensitive acetylcholinesterase (iAChEs) were implicated in insecticide resistance [28]. Pyrethroid insecticide resistance in An. stephensi from India and Iran was associated with increased activity of GES and GSTs [12, 17, 20, 21, 29]. Involvement of GSTs in insecticide resistance is evident in many insects, including mosquitoes [17, 18, 24].

Knockdown resistance $(k d r)$ mutation is widespread in Anopheles species in Africa especially Anopheles gambiae [30-35]. Originally, the L1014F mutation (later known as $k d r$ west) was detected. In 2000, a second $k d r$ mutation ( $k d r$ east) was detected in Kenyan An. gambiae [36], subsequently both mutations have been detected in other Anopheles conferring varying degrees of phenotypic pyrethroid resistance [5, 10, 37-43].

The first report of a $k d r$ L1014F resistance mechanism in An. stephensi was in the DUB-S strain in 2003 [19]. Recently, $k d r$ east and $k d r$ west mutations have been detected in An. stephensi from India [5]. In 2014, target site insensitivity for pyrethroid insecticides was studied in An. stephensi from Kunar and Nangarhar Provinces of Afghanistan [43]. The wild type susceptible L1014 allele in the sodium channel gene was the most prevalent followed by L1014S ( $k d r$ east, 21.4\%) and L1014F ( $k d r$ west, $1.4 \%)$, no $k d r$ homozygotes were collected.

The World Health Organization (WHO) recommends that insecticide susceptibility status of malaria vectors should be monitored annually [44, 45]. When insecticide resistance is detected, its intensity and the biochemical and molecular mechanisms should also be investigated $[44,45]$. Accurate information on the underlying resistance mechanisms and their intensity or frequency in malaria vectors can then inform vector control programmes and ensure timely management of insecticide resistance. Following the WHO Global Plan for Insecticide Resistance Management (GPIRM) [46], in this study the insecticide resistance status and its underlying mechanisms were investigated in An. stephensi from Kunar, Laghman and Nangarhar Provinces in eastern Afghanistan.

\section{Methods \\ Study area}

The study areas were the provinces of Kunar $\left(34.8466^{\circ} \mathrm{N}\right.$, $\left.71.0973^{\circ} \mathrm{E}\right)$, Laghman $\left(34.6898^{\circ} \mathrm{N}, 70.1456^{\circ} \mathrm{E}\right)$ and Nangarhar $\left(34.1718^{\circ} \mathrm{N}, 70.6217^{\circ} \mathrm{E}\right)$ in East Afghanistan (Fig. 1), sample site details are given in Table 1.

\section{Larval collection and mosquito rearing}

Thousands of larvae were collected from multiple breeding sites in the provinces of Kunar, Laghman and Nangarhar from 2014 to 2017 . Breeding sites with the highest larval density were used for sampling to obtain enough specimens for susceptibility tests and biochemical and molecular analyses.

Field collected larvae were reared to the adult at $25 \pm 2{ }^{\circ} \mathrm{C}$ temperature and $75 \pm 10 \%$ relative humidity. The adults were identified to species using Glick's identification keys [47]. Sugar-fed 3-4 days old adult $A n$. stephensi mosquito specimens were used for bioassays and biochemical and molecular analyses. The susceptible Beech strain of $A n$. stephensi was provided by the Department of Medical Entomology, School of Public Health, Tehran University of Medical Sciences, Iran.

\section{Insecticide susceptibility tests}

Insecticide susceptibility tests were carried out according to the standard WHO procedure for mosquito adults [45]. The WHO supplied insecticide-impregnated papers of DDT $4 \%$, malathion $5 \%$, bendiocarb $0.1 \%$, permethrin $0.75 \%$ and deltamethrin $0.05 \%$, were used for bioassays. Mosquitoes were divided into 


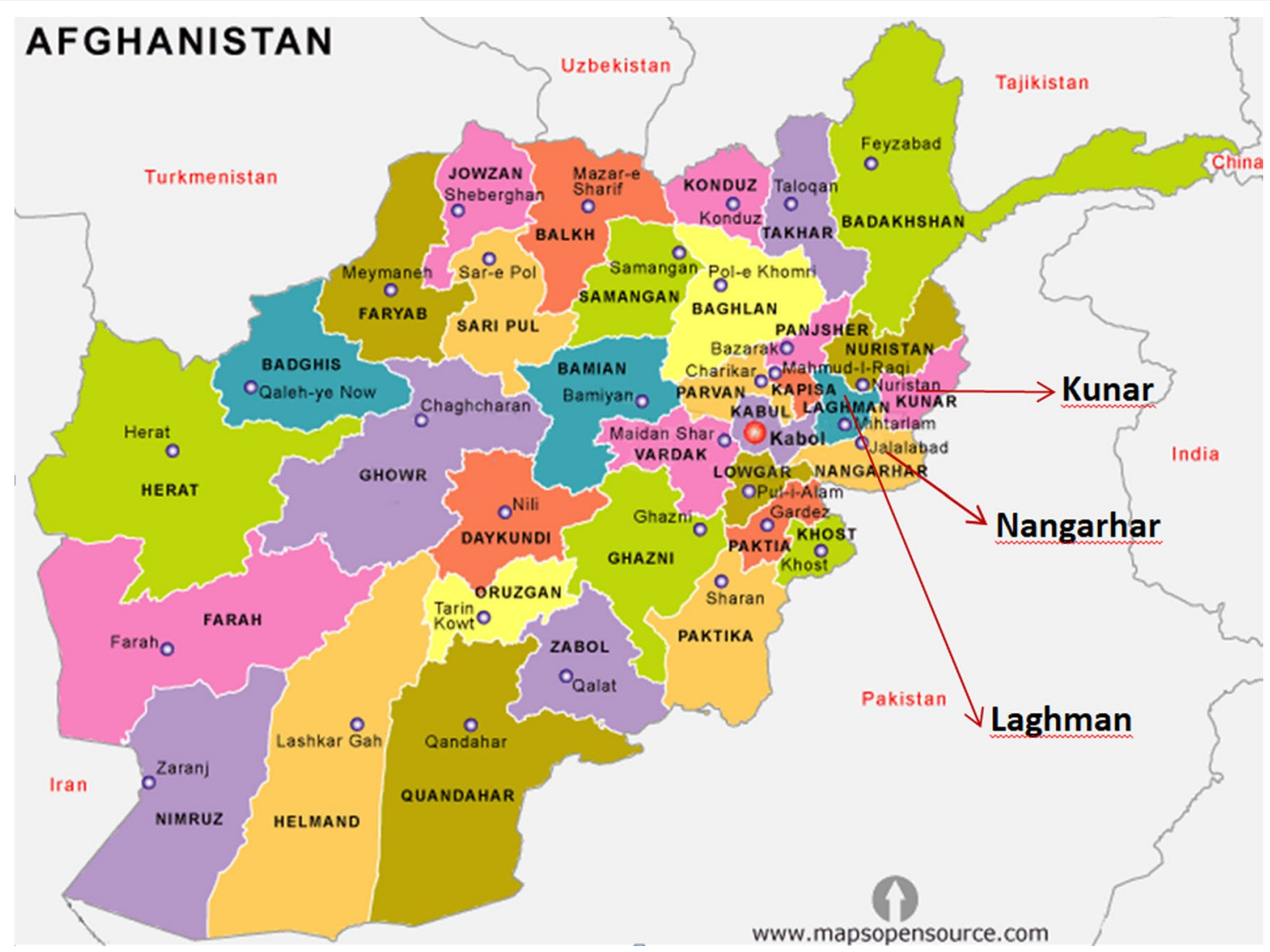

Fig. 1 Map of Afghanistan and the location of the provinces of Kunar, Nangarhar and Laghman

Table 1 Localization of sample collection sites and habitat description

\begin{tabular}{|c|c|c|c|c|c|c|}
\hline Province & District & Village & Habitat type & Elevation (m) & Altitude & Longitude \\
\hline \multirow[t]{2}{*}{ Kunar } & Nurgal & Nurgal & River stream & 658 & $34^{\circ} 36^{\prime} 45.70^{\prime \prime} \mathrm{N}$ & $70^{\circ} 46^{\prime} 31.76^{\prime \prime} \mathrm{E}$ \\
\hline & Chawkay & Babur & Pond, river stream & 711 & $34^{\circ} 41^{\prime} 26.04^{\prime \prime} \mathrm{N}$ & $67^{\circ} 30^{\prime} 42.61^{\prime \prime} \mathrm{E}$ \\
\hline \multirow[t]{3}{*}{ Laghman } & Mihtarlam & Tirgari & River stream & 735 & $34^{\circ} 38^{\prime} 41.03^{\prime \prime} \mathrm{N}$ & $70^{\circ} 12^{\prime} 36.20^{\prime \prime} \mathrm{E}$ \\
\hline & & Qarghayi & River stream & 644 & $34^{\circ} 32^{\prime} 53.46^{\prime \prime} \mathrm{N}$ & $70^{\circ} 14^{\prime} 29.18^{\prime \prime} \mathrm{E}$ \\
\hline & Qarghayi & Swati & River stream & 635 & $34^{\circ} 38^{\prime} 41.03^{\prime \prime} \mathrm{N}$ & $70^{\circ} 12^{\prime} 36.20^{\prime \prime} \mathrm{E}$ \\
\hline \multirow[t]{3}{*}{ Nangarhar } & Behsood & Bagrami & Pond/river stream & 571 & $34^{\circ} 26^{\prime} 49.08^{\prime \prime} \mathrm{N}$ & $70^{\circ} 24^{\prime} 24.94^{\prime \prime} \mathrm{E}$ \\
\hline & & Saracha & River streams & 540 & $34^{\circ} 23^{\prime} 13.70^{\prime \prime} \mathrm{N}$ & $70^{\circ} 32^{\prime} 23.52^{\prime \prime} \mathrm{E}$ \\
\hline & Samar Khel & Gujranu Bella & Swamp, river & 525 & $34^{\circ} 22^{\prime} 39.58^{\prime \prime} \mathrm{N}$ & $70^{\circ} 34^{\prime} 50.33^{\prime \prime} \mathrm{E}$ \\
\hline
\end{tabular}

batches of 25 before being exposed to the insecticidetreated papers for $1 \mathrm{~h}$. Experiments were conducted under insectary conditions with a minimum of four replicates per bioassay. For control replicates, siliconetreated papers were used. The results of the bioassay were discarded if the mortality of the control replicates was over $20 \%$. Abbott's formula was used to correct the mortality if it was between 5 and $20 \%$ [45].

\section{Biochemical assays}

The biochemical assays were performed according to the protocol of WHO/WHOPES [48]. The enzyme activity of GSTs and GES as well as the cytochrome P450s content and inhibition rates of AChE (using propoxur) were measured. 


\section{Molecular methods DNA isolation}

DNA from individual mosquitoes was extracted using the Livak buffer extraction method [49] with some modifications. Livak buffer contained $80 \mathrm{mM} \mathrm{NaCl}, 1.57 \%$ Tris Base, $0.5 \%$ sodium dodecyl sulfate (SDS), 5.5\% sucrose and $50 \mathrm{mM}$ EDTA. Individual mosquitoes were homogenized in $100 \mu \mathrm{l}$ pre-heated $\left(65^{\circ} \mathrm{C}\right)$ Livak buffer in $1.5 \mathrm{ml}$ Eppendorf tubes using a plastic pestle. Homogenates were incubated at $65{ }^{\circ} \mathrm{C}$ for $30 \mathrm{~min}$. Potassium acetate was added to each tube to a final concentration of $1 \mathrm{M}$ before incubating the mixture on ice for $30 \mathrm{~min}$. The tubes were centrifuged at $12,000 \mathrm{~g}$ for $15 \mathrm{~min}$ at $4{ }^{\circ} \mathrm{C}$. Supernatants were transferred to clean tubes and mixed with $200 \mu \mathrm{l}$ ice-cold ethanol, followed by centrifugation at $12,000 \mathrm{~g}$ for $15 \mathrm{~min}$ at $4{ }^{\circ} \mathrm{C}$. Pellets were rinsed in $100 \mu \mathrm{l}$ $70 \%$ ice-cold ethanol, spun at $12,000 \mathrm{~g}$ for $5 \mathrm{~min}$ at $4{ }^{\circ} \mathrm{C}$ and re-suspended in $50 \mu \mathrm{l}$ pre-heated Tris-EDTA (TE) buffer or nuclease free water.

\section{Primer design and $P C R$}

To obtain a fragment of voltage gated sodium channel (vgsc) encompassing the $k d r$ locus, a DNA section from IIS6 segment of An. stephensi was amplified using primers $k d r F\left(5^{\prime}\right.$-GGA CCA YGA TTT GCC AAG AT-3') and $k d r$ R (5'-TGG TGC AGA CAA GGA TGA AG-3') in a reaction mixture $(25 \mu \mathrm{l})$ that contained $1 \times$ buffer, $1.5 \mathrm{mM}$ of $\mathrm{MgCl} 2,200 \mu \mathrm{M}$ of each dNTP, $0.5 \mu \mathrm{M}$ of each primer and 0.625 unit of Taq DNA polymerase. The conditions of PCR were: an initial denaturation at $95{ }^{\circ} \mathrm{C}$ for $5 \mathrm{~min}$, followed by 35 cycles at $95^{\circ} \mathrm{C}$ for $30 \mathrm{~S}$, $48{ }^{\circ} \mathrm{C}$ for $30 \mathrm{~S}$ and $72{ }^{\circ} \mathrm{C}$ for $45 \mathrm{~S}$, and a final extension step at $72{ }^{\circ} \mathrm{C}$ for $7 \mathrm{~min}$. The PCR products were purified with Takapozist PCR purification kit (Takapozist, Iran) and were sequenced in both directions by Macrogen Inc, Korea using BigDye (Applied Biosystem Chemistry). A schematic diagram showing the stretch of the IIS6 of the sodium channel gene where the primers for cloning and screening sit is given in Fig. 2.

\section{Positive controls and cloning}

Positive control for $k d r$ east mutation (L1014S) was the courtesy of Dr. OM Singh, National Malaria Research Center, India. Positive control for the $k d r$ west mutation (L1014F) was from initial PCR screening of some specimens that survived bioassay using $k d r \mathrm{~F}$ and $k d r \mathrm{R}$ primers. Wild type positive control (L1014) was the product of PCR of two specimens from the susceptible Beech strain of An. stephensi with aforementioned primers. All positive control fragments were confirmed by sequencing and then cloned in pTG19-T system (Sinaclon, Iran) according to the manufacturer's instruction and used as positive control in genotyping reactions.

\section{Genotyping kdr alleles}

The screening method developed by Singh et al. was used in this study with some modifications [5]. Two PCR reactions were carried out for each DNA sample from individual mosquito specimens. In both PCRs, the forward primer used was $k d r F$. In the first PCR (hereafter called PCR-1), the allele 1014F is discriminated from the wild type (L1014) and in the second PCR (hereafter called PCR-2), 1014S and wild type alleles are discriminated. The allele-specific primers were the same used by Singh

Cloning primer forward

Exon

Exon
Seq TCTCTGCCTCTGCGCAACTCAATTTACTTGCAGATAATGTCGATCGATTCCCGGACCATGATCTGCCAAGATGGAATTTTACCGATTTCATGCACTCCTT

Seq CATGATTGTGTTCCGTGTGCTGTGCGGCGAATGGATCGAGTCCATGTGGGACTGTATGCTTGTCGGTGACGTGTCGTGCATACCCTTTTTCCTAGCTACA

Seq GTAGTGATAGgAAATYWGTCGTAAGTAACTTACTTTCCGATCGCAATCGTGTGCAATCCAGACCAGTGCAGTAGAACCAAAAATAACTTCTCTCTCTCT

Seq CTCTCTCTCTCTCTCTCTCTCTCTCTCTTTTACGCAGGTTCTCAACCTTTTCTTAGCCTTGCTTTTGTCGAATTCGGTTCTTCATCGCTGTCCGCACCG

Seq ACGGCCGACAACGAGACCAACAAGATTGCGGAAGCGTTTAACCGAATCTCGCGCTTTTCTAACTGGATCAAGATGAACGTGGCGAACGCGCTTAAGTTTG

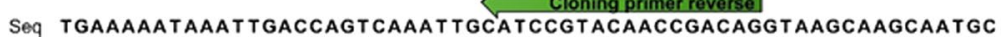

Fig. 2 Schematic diagram of a IIS6 fragment of vgsC gene where the primers for cloning and screening sit 
et al. [5]. They are St-L/SR (5'-GCG GGC AGG GCG GCG GGG GCG GGG CCC GAT CGG AAA GTA AGT TAC TTA CGt CT-3') and St-PheR (5'-GAT CGG AAA GTA AGT TAC TTA CGg CA-3') for PCR-1, and St-LeuR (5'-GCG GGC AGG GCG GCG GGG GCG GGG CCC GAT CGG AAA GTA AGT TAC TTA CGA gTA-3') and St-SerR (5'-CGA TCG GAA AGT AAG TTA CTT ACG AtT G-3') for PCR-2. The expected amplicon size formed by the allele-specific primers St-L/SR and St-PheR (with primer $k d r F$ ) in PCR-1 are 218 and 191 bp receptively. The expected size of amplicons in PCR-2 with allele specific primers St-LeuR and St-SerR are 218 and $192 \mathrm{bp}$, respectively.

\section{Data management, transformation and analyses}

The reading of the activity/content of the enzymes were done in a UV/visible microtitre plate reader (BioTek, USA) run under $\mathrm{KC}$ junior software and the data were directly extracted to Microsoft Excel for further analysis. Mean values of activity or contents of each enzyme of all populations were compared by ANOVA in conjunction with the Tukey's statistical test using SPSS version 19 software. Enzyme ratios (ER) were calculated by dividing the mean activities or content of the enzymes in the field populations with those of the Beech susceptible strain.

The molecular analyses data were calculated based on the frequency of $k d r$ mutations in An. stephensi populations from different provinces in dead or alive specimens following bioassays. Hardy Weinberg equilibrium software was used for analysis between different $k d r$ genotypes [50].

\section{Results}

\section{Mosquito samples}

Approximately 2250, 1800 and 2250 3-4 days old adult mosquitoes were used for bioassays in 2014, 2015 and 2017, respectively. Two hundred 3-4 days old adult mosquito specimens were used for biochemical assays. Dead and alive adult mosquitoes following bioassays with deltamethrin from each population were used for molecular analysis.

\section{Bioassay}

Considering the susceptibility threshold of a mortality rate above $98 \%$, then only one population of An. stephensi from Kunar was susceptible to bendiocarb and the Laghman and Nangarhar populations were resistant to all insecticides tested. When bioassay mortalities in 2014 were compared to those of 2017, there was a reduction of $27 \%$ in susceptibility to permethrin in Kunar population, while the susceptibility to permethrin in the other two field populations remained more or less the same. Susceptibility to deltamethrin was the same in 2014 and
2017 in Kunar population, whereas an increase of about $30 \%$ in susceptibility to deltamethrin was observed in the other two field populations. Regarding susceptibility to malathions, reduction of $55 \%, 46 \%$ and $41 \%$ were monitored in the Kunar, Laghman and Nangarhar populations, respectively. The susceptibility to bendiocarb increased 3\% in the Kunar population, changing the status of this population from being resistant to susceptible. The susceptibility to bendiocarb in the other two field populations decreased $43.5 \%$ and $16 \%$. Surprisingly, the susceptibility to DDT increased $55 \%$ in the Kunar population, however, in Laghman population it reduced about $44 \%$ while it remained the same in the Nangarhar population (Table 2).

\section{Esterase activity}

The esterase activity ratios of An. stephensi from Kunar, Laghman and Nangarhar Provinces in East Afghanistan compared to the susceptible Beech strain are given in Table 3 . The mean activity of alpha- and beta-naphthyl acetate were 0.000983 and $0.000961 \mu \mathrm{M} / \mathrm{min} / \mathrm{mg}$ protein in the Kunar population, 0.001 and $0.001 \mu \mathrm{M} / \mathrm{min} /$ $\mathrm{mg}$ protein in the Laghman population and 0.000911 and $0.000904 \mu \mathrm{M} / \mathrm{min} / \mathrm{mg}$ protein in the Nangarhar population and 0.000517 and $0.000567 \mu \mathrm{M} / \mathrm{min} / \mathrm{mg}$ protein in the susceptible Beech strain. The esterase activities of mosquitoes from the Kunar, Laghman and Nangarhar populations were statistically significantly higher than those of the susceptible Beech strain at the 5\% level. The esterase activity in the Laghman population was marginally higher than those of the Kunar and Nangarhar populations (Table 3).

\section{GSTs activity}

The activity of the GSTs in the Laghman and Nangarhar populations were significantly higher than that of the susceptible Beech strain, however, the differences between the GST activity of Kunar population was not significantly different from that of the susceptible strain (Table 3).

\section{Cytochrome P450s contents}

The ratio of cytochrome P450s in the Kunar, Laghman and Nangarhar populations were 2.68, 2.37 and 2.45 when compared with that of the susceptible Beech strain (Table 3). However, the differences of the cytochrome P450 contents between the Kunar, Laghman and Nangarhar populations were not statistically significant (Table 3).

\section{AChE inhibition}

The AChE inhibition rates with the carbamate propoxur were $68.63 \%$ in the susceptible Beech strain, $51.98 \%$ in 
Table 2 Percentage mortality of bioassays on An. stephensi adults using different insecticides in 2014 to 2017

\begin{tabular}{llllll}
\hline Insecticide & Province & $\mathbf{2 0 1 4}$ & $\mathbf{2 0 1 5}$ & $\mathbf{2 0 1 7}$ & $\begin{array}{l}\text { Percentage changes in the susceptibility } \\
\text { compared to the 2014 baseline }\end{array}$ \\
\hline Permethrin 0.75\% & Kunar & 89 & 89 & 65 & -27 \\
& Laghman & 90 & 87 & 91 & +1 \\
& Nangarhar & 92 & 92.2 & 90 & -2 \\
Deltamethrin 0.05\% & Kunar & 78 & 85 & 78 & 0 \\
& Laghman & 65 & 63 & 93 & 43 \\
Nalathion 5\% & Nangarhar & 66 & 95 & 90 & 36 \\
& Kunar & 62 & 88 & 28 & -55 \\
& Laghman & 95 & 85 & 51 & -46 \\
Bendiocarb 0.1\% & Nangarhar & 95 & 86 & 56 & -41 \\
& Kunar & 95 & 90 & 98 & +3 \\
& Laghman & 92 & 63 & 52 & -43.5 \\
DDT 4\% & Nangarhar & 100 & 86 & 84 & -16 \\
& Kunar & 45 & NA & 70 & +55.5 \\
& Laghman & 80 & NA & 45 & -44 \\
& Nangarhar & 60 & NA & 60 & 0 \\
\hline
\end{tabular}

the Kunar population, $48.82 \%$ in the Laghman population and $53.14 \%$ in the Nangarhar population (Table 3). The inhibition levels in all field populations were lower than the threshold of $60 \%$ set for considering the AChE

Table 3 Mean enzyme activities and enzyme ratios (ER) measured in An. stephensi populations from Afghanistan

\begin{tabular}{llll}
\hline Enzyme & Population & Mean & ER \\
\hline Alfa esterase & Susceptible & 0.000517 & 1 \\
& Kunar & 0.000983 & 1.90 \\
& Laghman & 0.001050 & 2.03 \\
& Nangarhar & 0.000917 & 1.77 \\
Beta esterase & Susceptible & 0.000567 & 1 \\
& Kunar & 0.000961 & 1.69 \\
& Laghman & 0.001075 & 1.89 \\
& Nangarhar & 0.000904 & 1.59 \\
GST & Susceptible & 0.11445 & 1 \\
& Kunar & 0.16204 & 1.41 \\
& Laghman & 0.23021 & 2.01 \\
cytochrome p450 & Nangarhar & 0.21822 & 1.90 \\
& Susceptible & 0.0000491 & 1 \\
& Kunar & 0.0001316 & 2.68 \\
& Laghman & 0.0001167 & 2.37 \\
& Nangarhar & 0.0001204 & 2.45 \\
& Susceptible & 68.63 & 1 \\
& Kunar & 51.98 & 0.75 \\
& Laghman & 48.82 & 0.71 \\
& Nangarhar & 53.14 & 0.77 \\
\hline
\end{tabular}

ERs are the results of the mean enzyme activity or content of the field populations divided by those of the susceptible Beech population. \%AChE inhibition is the percentage of acetylcholinesterase inhibition of the field populations compared with the susceptible Beech population insensitive to propoxur. There were significant differences between the three populations in AChE inhibition when compared with that of the susceptible Beech strain $(p>0.001)$. However, the differences between the inhibition rates of $\mathrm{AChE}$ in the field populations were not statistically significant from each other $(p=0.09)$. The frequency of individuals with iAChE (inhibition less than $60 \%$ with propoxur) were $37 \%, 64 \%, 78 \%$ and $75 \%$ in susceptible, Kunar, Laghman and Nangarhar populations of An. stephensi, respectively.

In summary, the differences between the activities/ contents of all the enzymes measured in this study in the Kunar, Laghman and Nangarhar populations were statistically significant compared with those of the susceptible Beech strain. The Laghman population had a marginally higher enzymes activities/content compared with the other Afghan field populations.

\section{kdr genotyping}

Primers designed to amplify a flanking region encompassing the SII6 region containing the $k d r$ codon of the vgsc of An. stephensi gave a $493 \mathrm{bp}$ product, the results of sequencing this region are shown in Fig. 2. The cloned products of the $k d r$ alleles were used as positive control in genotyping reactions.

Using the forward primer designed in this study and four reverse primers, a total of 180 mosquitoes were successfully genotyped for all three different alleles (homozygote and heterozygote) of wild type, $k d r$ west and $k d r$ east (Fig. 3). The results are summarized in Table 4.

The total frequency of $k d r$ west in all populations was $4.44 \%$ ( 5 heterozygotes and 3 homozygotes). The 
frequency of $k d r$ in the three populations of Kunar, Laghman and Nangarhar were not significantly different. The frequency of the $k d r$ alleles in pyrethroid bioassay survivors were, however, significantly different from the dead mosquitoes in all populations tested. Seven out of $8 k d r$ west mutated individuals were among bioassay survivors. Individuals homozygote for $k d r$ west were detected only in the bioassay survivors (one in each population).

The frequency of $k d r$ east was significantly higher than $k d r$ west. The overall frequency of $k d r$ east was $29 \%$. The frequency of $k d r$ east in the alive and dead specimens of the studied populations were $38 \%$ and $26.7 \%$, respectively. The frequency of $k d r$ east in Nangarhar, Laghman and Kunar populations were 35\%, 32.7\% and 22.9\% respectively. Three of the four homozygote $k d r$ east mutants were among the bioassay survivors.

Regardless of the type of the mutated alleles, the frequency of $k d r$ in all populations were $33.33 \%$. The frequency of $k d r$ east and west combined in the populations were in the order of Nangarhar 39.6\%, Laghman 37.9\% and Kunar 27.9\%. The allelic frequency of Leucin, Serine and Phenylalanine were $0.814,0.156$ and 0.03 respectively, all within the HWE $(\mathrm{p}=0.14)$.

\section{Discussion}

A general reduction in the susceptibility of An. stephensi from the eastern provinces of Afghanistan in recent years is probably in part due to the development of agriculture $[51,52]$ and increased use of different classes of insecticides that exerted a selection pressure on mosquitoes, especially where the larval breeding sites are within or close to the rice fields [43]. The increase in resistance was most obvious to organophosphates and carbamates. Interestingly, the susceptibility to deltamethrin increased in the Laghman and Nangarhar populations, whereas to bendiocarb, it decreased in these populations. It might be due to the recent use of bendiocarb in rotation with deltamethrin in the region. Although resistance to bendiocarb has been reported in different mosquito species

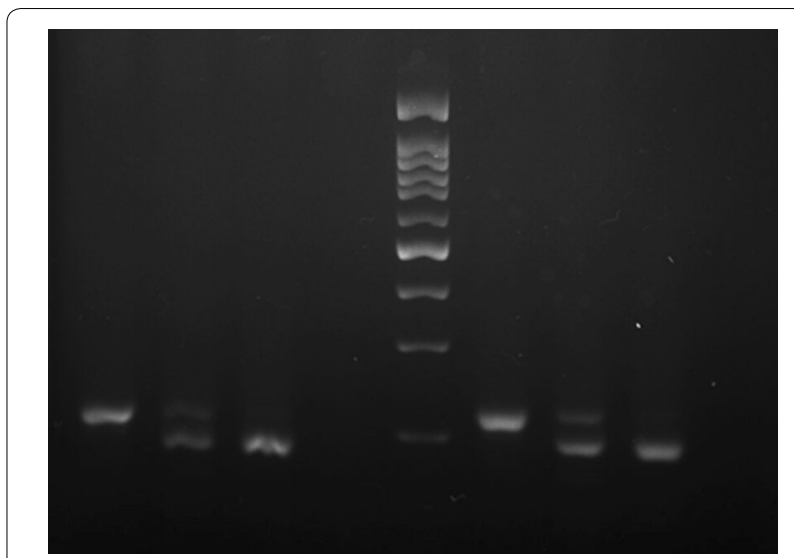

Fig. 3 Banding pattern of the kdr genotyping of An. stephensi specimens from Kunar, Laghman and Nangarhar populations from Afghanistan. Lanes 1: LL, 2: L/F, 3: F/F, 4: negative control, 5: $100 \mathrm{bp}$ DNA ladder, 6: L/L, 7: L/S, 8: S/S

[53-56], development of bendiocarb resistance in $A n$. stephensi populations in Afghanistan is now a cause for concern for the malaria control programme, who use this in IRS as an alternative to deltamethrin, in combination with LNs to manage insecticide resistance [2]. Malathion and bendiocarb share the same mode of action and have the same target site resistance mechanism $[57,58]$. The recent selection of bendiocarb resistance combined with the longstanding resistance to malathion $[4,9]$ suggests multiple resistance mechanisms in the Laghman population of An. stephensi.

Differential patterns of selection of insecticide resistance in populations of An. stephensi in different provinces of Kunar, Laghman and Nangarhar were observed [6]. For example, the Kunar population remained susceptible to bendiocarb whereas the populations in Laghman and Nangarhar developed resistance to this insecticide between 2014 and 2017. Resistance levels to the pyrethroid insecticides permethrin and deltamethrin remained low, suggesting that resistance is conferred only by the relatively weak $k d r$ mechanism.

Table 4 The results of screening kdr mutations in the field populations of An. stepehsni from Kunar, Laghman and Nangarhar Provinces collected from Afghanistan in 2017

\begin{tabular}{|c|c|c|c|c|c|c|c|}
\hline Strain & $\begin{array}{l}\text { Dead/alive } \\
\text { after bioassay }\end{array}$ & $\begin{array}{l}\text { Kdr-west, } \\
\text { homozygote }\end{array}$ & $\begin{array}{l}\text { Kdr-west } \\
\text { heterozygote }\end{array}$ & $\begin{array}{l}\text { Kdr-east } \\
\text { homozygote }\end{array}$ & $\begin{array}{l}\text { Kdr-east } \\
\text { heterozygote }\end{array}$ & $\begin{array}{l}\text { Wild type } \\
\text { homozygote }\end{array}$ & Subtotal \\
\hline \multirow[t]{2}{*}{ Laghman } & Alive & 1 & 2 & 1 & 6 & 12 & 22 \\
\hline & Dead & 0 & 0 & 0 & 12 & 27 & 39 \\
\hline \multirow[t]{2}{*}{ Kunar } & Alive & 1 & 1 & 1 & 4 & 13 & 20 \\
\hline & Dead & 0 & 1 & 1 & 8 & 34 & 44 \\
\hline \multirow[t]{2}{*}{ Nangarhar } & Alive & 1 & 1 & 1 & 8 & 9 & 20 \\
\hline & Dead & 0 & 0 & 0 & 10 & 25 & 35 \\
\hline Subtotal & & 3 & 5 & 4 & 48 & 120 & 180 \\
\hline
\end{tabular}


Biochemical assays suggested that multiple metabolic mechanisms of resistance may have been selected in An. stephensi from Afghanistan. GST-based metabolism is often associated with DDT resistance [59-61]. GSTs activities were the highest in Laghman population compared with the other two field populations, and DDT resistance levels in Laghman population were the highest among all three field populations. Besides involving in DDT resistance, GSTs may be secondarily involved in pyrethroid insecticide resistance, so care must be taken in interpretation of the dynamics of this enzyme group as its metabolic role is not restricted to DDT [62].

Cytochrome P450s content in the Kunar, Nangarhar and Laghman populations of An. stephensi is increasing. Implications of this information for looking at the potential for moving to the new generations of PBO LNs should be considered [63]. There are evidence that PBO LNs improved control of malaria transmission compared with standard long-lasting insecticidal nets where pyrethroid resistance is prevalent [64].

The mean inhibition rates and frequency of iAChE individuals in the field populations of An. stephensi from Afghanistan are significantly higher than that of the susceptible Beech strain. The iAChE should confer resistance to malathion and bendiocarb in An. stephensi [65, 66].

The importance of different enzyme groups in conferring insecticide resistance in different insects, especially mosquitoes, is overwhelming [12, 21, 23, 24, 27, 29, 55]. General esterases and cytochrome P450s are involved in pyrethroid insecticide resistance in An. stephensi from Dubai, Iran and India [12, 20, 21, 23, 67]. Esterases also confer resistance to OPs and to a lesser extent to pyrethroid insecticides $[19,68]$. Involvement of $\mathrm{iAChE}$ in OPs and carbamate insecticides resistance is evident in many insect groups including An. stephensi from Iran, Afghanistan and India [12, 23, 27, 28]. A similar pattern of AChE insensitivity was seen in Anopheles albimanus in Mexico [69], in Turkish populations of the Anopheles maculipennis [70], and An. stephensi from Iran [13]. The reduction in susceptibility of An. stephensi from Afghanistan to bendiocarb in recent years [6] is of concern, as it is the insecticide of choice for IRS and insecticide resistance management in the East of Afghanistan is reliant on this in combination with LN distribution [2]. Close monitoring is now required to ensure that the situation does not deteriorate and impact on the ability to control malaria.

The current study suggests that both metabolic and target site resistance have increased between 2014 and 2017 in Afghanistan. Knock down resistance mechanism of pyrethroid resistance in An. stephensi was first determined in 2003 by Enayati et al. [19] in the DUB-S strain. At that time, only L1014F (later known as $k d r$ west) mutation was observed in the species. After the discovery of L1014S mutation (known as kdr east) in An. gambiae in Kenya [36], reports of the presence of this trait in different mosquito species emerged [37, 38, 40, 71]. The presence of $k d r$ east in An. stephensi from India was reported for the first time by Singh et al. [5]. The development of $k d r$ mechanism in An. stephensi from Afghanistan was first reported in 2016 [43], a report that triggered this bigger study in populations of An. stephensi from Kunar, Laghman and Nangarhar.

The overall frequency of $k d r$ east in Afghan An. stephensi has increased by $8 \%$ between 2016 and 2017 [43]. The $k d r$ mutants were significantly more frequent in bioassay survivors compared to dead (38\% vs $27 \%)$, as expected from this relatively weak pyrethroid resistance mechanism. The allelic frequency of $k d r$ east was much lower than that reported in an Indian population of $A n$. stephensi [5], however, the allelic frequency of $k d r$ west was higher. $K d r$ west and east are prevalent in different Anopheles species worldwide [72, 73]. In An. gambiae in many West African countries, the frequency of $k d r$ west has reached fixation (total homozygocity) [54, 74-77]. In other parts of Africa, co-occurrence of $k d r$ west and $k d r$ east with relatively high frequency is reported [34, 37, 71, $73,78]$. It has been argued that even with high $k d r$ mutation rates, LNs may still be effective in protecting people against malaria [79-85]. However, a systematic review with meta-analysis revealed that the efficacy of the LNs diminishes with high intensity insecticide resistance [86, 87].

The development of different $k d r$ traits may reflect the history of phenotypic resistance to different classes of insecticides. It was shown that $k d r$ west confers stronger resistance to pyrethroid insecticides compared with $k d r$ east, as the latter confers higher resistance to DDT and lesser to pyrethroids [88]. The susceptibility of Laghman population of An. stephensi to DDT (45\%) is lower compared to Kunar (the highest 70\%) and Nangarhar populations (60\%).

The proportion of arable land to the total area of the country is in the order of Nangarhar $(12 \%)>$ Kunar (7\%) > Laghman (4\%) [52]. The intensive use of organophosphorus and carbamate insecticides in agriculture, coupled with the historical and current use of these insecticides in public health has selected increasing levels of resistance to malathion and bendiocarb in Afghan An. stephensi between 2014 and 2017 [6]. Larviciding with temephos and IRS using bendiocarb may exacerbate the levels of resistance to these classes of insecticides in $A n$. stephensi.

The results of biochemical assays support the development of resistance to all classes of insecticides in An. stephensi in these provinces. A detailed resistance 
management plan should now be prepared to address potential issues going forward before resistance problem start to reduce the effectiveness of malaria control.

\section{Conclusions}

Anopheles stephensi populations from Kunar, Laghman and Nangarhar developed a range of resistance to different insecticides. Resistance to DDT, malathion, bendiocarb and pyrethroid insecticides is evident in different populations of the mosquito. Different enzyme groups are involved in the resistance to insecticides in An. stephensi from Kunar, Laghman and Nangarhar Provinces of Afghanistan. The contents of cytochrome P450s and the levels of activities of general esterases, glutathione $S$-transferases and the insensitivity of acetylcholinesterase are increasing in these populations. Based on the results, it can be concluded that the strength of metabolic resistance in An. stephensi from Laghman is slightly higher to multiple insecticides than the other two field populations. Knockdown resistance (both L1014F and L1014S) gene frequency is also on the rise. Moreover, homozygote individuals for either $k d r$ traits have been detected for the first time in the field populations. These observations have huge technical as well as practical implications to malaria control programmes in Afghanistan. Based on these observations, the following general recommendations can be made: (i) vector control programmes need to be evidence-based and to be guided by routine monitoring and evaluation of vector control interventions including susceptibility to insecticides; (ii) malaria vector control is implemented based on careful stratification which includes, among other things, vector susceptibility to insecticides and their underlying resistance mechanisms; (iii) close collaboration of public health and agriculture sectors is required for effective management of insecticide resistance. In other words, for sound insecticide resistance management, implementation of strategies such as IVM in public health and IPM in agriculture is recommended. On the other hand, in planning and implementation of control measures for vectorborne diseases especially malaria, considerations should be made not only to the growing insecticide resistance status in the vectors, but also to its mechanisms in $A n$. stephensi in the East of Afghanistan. Given the differential development of insecticide resistance and its underlying mechanisms in An. stephensi populations from different provinces of Afghanistan, it is recommended that the malaria control planning be province specific e.g. applying bendiocarb IRS in Kunar where An. stephensi is susceptible to this insecticide, while deploying PBO nets in Laghman and Nangarhar Provinces where cytochrome $\mathrm{P} 450$ is involved in pyrethroid insecticides resistance.
LNs with alternative insecticides e.g. chlorfenapyr, and primiphos methyl long lasting IRS may also be answers to some of the challenges of insecticide resistance in $A n$. stephensi in Afghanistan.

\section{Abbreviations}

iAChE: insensitive acetylcholinesterase; AChE: acetylcholinesterase; bp: base pair; DDT: dichlorodiphenyltrichloroethane; EDTA: ethylenediaminetetraacetic acid; GPIRM: global plan for insecticide resistance management; GES: general esterase; GST: glutathione S-transferase; HWE: Hardy-Weinberg equilibrium; IRS: indoor residual spraying; KDR: knockdown resistance; LNs: longlasting insecticidal nets; MoPH: Ministry of Public Health; NLMCP: National Malaria and Leishmaniasis Control Programme; OPs: organophosphates; PCR: polymerase chain reaction; P450s: cytochrome P450s; SDS: sodium dodecyl sulfate; TE: Tris-EDTA; VGSC: voltage gated sodium channel; WHO: World Health Organization; WHOPES: World Health Organization Pesticide Evaluation Scheme.

\section{Acknowledgements}

This project was supported financially by the WHO Regional Office for the Eastern Mediterranean and WHO country office Afghanistan. Thanks also to the personnel of the biochemistry of pesticide lab and Cellular and Molecular Biology Research Center at School of Public Health and Faculty of Medicine, Mazandaran University of Medical Sciences, Iran for their assistance in biochemical and molecular analyses of the specimens.

\section{Authors' contributions}

NHZS and AAA collected the Anopheles specimens from Kunar, Laghman and Nangarhar and performed the bioassays. SN and SW coordinated the project, sample collection and the work in Afghanistan. RV supervised the molecular analyses. AS and MS helped with the PCR. AAE designed the study, oversaw the biochemical assays, analyzed the data and drafted the manuscript. JH was involved in the project conception and critically reviewed the manuscript. All authors read and approved the final manuscript.

\section{Funding}

This project was supported financially by WHO Regional Office for the Eastern Mediterranean and technically by WHO country office Afghanistan and Iran.

\section{Availability of data and materials}

All data generated or analysed during this study are included in this published article.

\section{Ethics approval and consent to participate}

Not applicable.

\section{Consent for publication}

Not applicable.

\section{Competing interests}

The authors declare that they have no competing interests.

\section{Author details}

${ }^{1}$ National Malaria and Leishmania Control Programme, Ministry of Public Health, Kabul, Afghanistan. ${ }^{2}$ World Health Organization, Kabul, Afghanistan. ${ }^{3}$ Department of Immunology, Faculty of Medicine, Mazandaran University of Medical Sciences, Sari, Iran. ${ }^{4}$ Molecular and Cell Biology Research Center (MCBRC), Faculty of Medicine, Mazandaran University of Medical Sciences, Sari, Iran. ${ }^{5}$ Department of Medical Entomology and Vector Control, School of Public Health and Health Sciences Research Centre, Mazandaran University of Medical Sciences, Sari, Iran. ${ }^{6}$ Liverpool School of Tropical Medicine, Liverpool, UK.

Received: 27 March 2019 Accepted: 18 July 2019

Published online: 26 July 2019 


\section{References}

1. WHO. World malaria report. Geneva: World Health Organization; 2018

2. Afghanistan Ministry of Public Health. National Malaria Strategic Plan 2013-2017. Islamic Republic of Afghanistan. Kabul: Afghanistan Ministry of Public Health; 2013

3. Rowland M, Mohammed N, Rehman H, Hewitt S, Mendis C, Ahmad M, et al. Anopheline vectors and malaria transmission in eastern Afghanistan. Trans R Soc Trop Med Hyg. 2002;96:620-6.

4. Safi N, Hameed H, Sediqi W, Himmat E. National Malaria and Leishmaniasis Control Programme (NMLCP) Annual Report, 2008. Afghan Annu Malar J. 2009;1:8-14.

5. Singh $O P$, Dykes $C L$, Lather $M$, Agrawal OP, AdakT. Knockdown resistance $(\mathrm{kdr})$-like mutations in the voltage-gated sodium channel of a malaria vector Anopheles stephensi and PCR assays for their detection. Malar J. 2011;10:59.

6. Safi NHZ. Status of insecticide susceptibility in Laghman, Kunar and Nangarhar Provinces, Afghanistan in 2017. Kabul: Ministry of Public Health, Afghanistan; 2017.

7. Ministry of Public Health. National malaria strategic plan 2013-1017. National Malaria and Leishmaniasis Control Programme; 2013. http:// moph.gov.af/Content/Media/Documents/NationalStrategicPlanforMalari aControlandElimination184201510534818553325325.doc. Accessed 26 Dec 2018.

8. Ahmad M. Evaluating insecticide resistance status in wild-caught Anopheles mosquitoes in Afghanistan. Kabul: HealthNet-TPO; 2015.

9. Barwa C. Status of Insecticide sSusceptibility in Afghanistan. (General Directorate of Preventive Medicine and Primary Health Care CDD National Malaria and Leishmaniasis Control Programme, Afghanistan: Ministry of Public Health, Islamic Republic of Afghanistan; 2011. https:// moph.gov.af/Content/Media/Documents/NationalStrategicPlanforMalari aControlandElimination184201510534818553325325.doc. Accessed 26 Dec 2018.

10. Singh OP, Dykes CL, Adak T. Kdr-like mutations in the voltage gated sodium channel of a malaria vector Anopheles stephensi and development of PCR-based assays for their detection. Malar J. 2010;9(Suppl 2):P67.

11. Soltani A, Vatandoost H, Oshadhi MA, Enayati AA, Raeisi A, Eshraghian MR, et al. Baseline susceptibility of different geographical strains of Anopheles stephensi (Diptera: Culicidae) to temephos in malarious areas of Iran. J Arthropod-Borne Dis. 2013;7:56-65.

12. Soltani A, Vatandoost H, Oshaghi MA, Ravasan NM, Enayati AA, Asgarian F. Resistance mechanisms of Anopheles stephensi (Diptera: Culicidae) to temephos. J Arthropod-Borne Dis. 2014;9:71-83.

13. Soltani A, Vatandoost $H$, Oshaghi MA, Ravasan NM, Enayati AA, Asgarian F. Resistance mechanisms of Anopheles stephensi (Diptera: Culicidae) to temephos. J Arthropod-borne Dis. 2015;9:71-83.

14. Dykes CL, Das MK, Eapen A, Batra CP, Ghosh SK, Vijayan VA, et al. Knockdown resistance $(k d r)$ mutations in Indian Anopheles stephensi (Diptera: Culicidae) populations. J Med Ent. 2016;53:315-20.

15. Gorouhi MA, Vatandoost H, Oshaghi MA, Raeisi A, Enayati AA, Mirhendi $\mathrm{H}$, et al. Current susceptibility status of Anopheles stephensi (Diptera: Culicidae) to different imagicides in a malarious area, Southeastern of Iran. J Arthropod-borne Dis. 2016;10:493-500.

16. Mogaddam MY, Haghi FM, Fazeli-Dinan M, Hoseini N, Enayati AA. A review of insecticide resistance in malaria vectors of Iran. J Mazandaran Univ Med Sci. 2016;25:394-411.

17. Enayati AA, Ladonni H. Biochemical assays baseline data of permethrin resistance in Anopheles stephensi (Diptera, Culicidae) from Iran. Pak J Biol Sci. 2006;9:1265-70.

18. Enayati AA, Ranson H, Hemingway J. Insect glutathione transferases and insecticide resistance. Insect Mol Biol. 2005;14:3-8.

19. Enayati AA, Vatandoost H, Ladonni H, Townson H, Hemingway J. Molecular evidence for a $k d r$-like pyrethroid resistance mechanism in the malaria vector mosquito Anopheles stephensi. Med Vet Entomol. 2003;17:138-44.

20. Ganesh K, Vijayan V, Urmila J, Gopalan N, Prakash S. Role of esterases and monooxygenase in the deltamethrin resistance in Anopheles stephensi Giles (1908), at Mysore. Indian J Exp Biol. 2002;40:583-8.

21. Ganesh KN, Urmila J, Vijayan VA. Pyrethroid susceptibility \& enzyme activity in two malaria vectors, Anopheles stephensi (Liston) \& Anopheles culicifacies (Giles) from Mysore, India. Indian J Med Res. 2003;117:30-8.
22. Gayathri V, Balakrishna Murthy P. Reduced susceptibility to deltamethrin and kdr mutation in Anopheles stephensi Liston, a malaria vector in India. J Am Mosq Control Assoc. 2006;22:678-88.

23. Hariprasad TP, Shetty NJ. Biochemical basis of alphamethrin resistance in different life stages of Anopheles stephensi strains of Bangalore, India. Pest Manag Sci. 2016;72:1689-701

24. Hemingway J. The molecular basis of two contrasting metabolic mechanisms of insecticide resistance. Insect Biochem Mol Biol. 2000;30:1009-15.

25. Hemingway J, Ranson $\mathrm{H}$. Insecticide resistance in insect vectors of human disease. Annu Rev Entomol. 2000;45:369-89.

26. Hodjati MH, Curtis CF. Genetics of resistance to permethrin in Anopheles stephensi. J Vector Borne Dis. 2003;40:60-3.

27. Prasad KM, Raghavendra K, Verma V, Velamuri PS, Pande V. Esterases are responsible for malathion resistance in Anopheles stephensi: A proof using biochemical and insecticide inhibition studies. J Vector Borne Dis. 2017:54:226-32.

28. Safi NHZ, Ahmadi AA, Nahzat S, Ziapour SP, Nikookar SH, Fazeli-Dinan M, et al. Evidence of metabolic mechanisms playing a role in multiple insecticides resistance in Anopheles stephensi populations from Afghanistan. Malar J. 2017;16:100.

29. Sanil D, Shetty V, Shetty N. Differential expression of glutathione s-transferase enzyme in different life stages of various insecticide-resistant strains of Anopheles stephensi: a malaria vector. J Vector Borne Dis. 2014;51:97-105.

30. Djègbè I, Boussari $O$, Sidick A, Martin T, Ranson $H$, Chandre $F$, et al. Dynamics of insecticide resistance in malaria vectors in Benin: first evidence of the presence of L1014S kdr mutation in Anopheles gambiae from West Africa. Malar J. 2011;10:261.

31. Aïzoun N, Aïkpon R, Akogbéto M. Evidence of increasing L1014F kdr mutation frequency in Anopheles gambiae s.l. pyrethroid resistant following a nationwide distribution of LLINs by the Beninese National Malaria Control Programme. Asian Pac J Trop Biomed. 2014;4:239-43.

32. Ibrahim SS, Manu YA, Tukur Z, Irving H, Wondji CS. High frequency of $k d r$ L1014F is associated with pyrethroid resistance in Anopheles coluzzii in Sudan savannah of northern Nigeria. BMC Infect Dis. 2014;14:441.

33. Camara S, Koffi AA, Ahoua Alou LP, Koffi K, Kabran JPK, Koné A, et al. Mapping insecticide resistance in Anopheles gambiae (s.l.) from Côte d'Ivoire. Parasit Vectors. 2018:11:19.

34. Thiaw O, Doucouré S, Sougoufara S, Bouganali C, Konaté L, Diagne N, et al. Investigating insecticide resistance and knock-down resistance $(k d r)$ mutation in Dielmo, Senegal, an area under long lasting insecticidaltreated nets universal coverage for 10 years. Malar J. 2018;17:123.

35. Zoh DD, Ahoua Alou LP, Toure M, Pennetier C, Camara S, Traore DF, et al. The current insecticide resistance status of Anopheles gambiae (s.l.) (Culicidae) in rural and urban areas of Bouaké. Côte d'Ivoire. Parasit Vectors. 2018;11:118.

36. Ranson $H$, Jensen B, Vulule JM, Wang X, Hemingway J, Collins FH. Identification of a point mutation in the voltage-gated sodium channel gene of Kenyan Anopheles gambiae associated with resistance to DDT and pyrethroids. Insect Mol Biol. 2000;9:491-7.

37. Pinto J, Lynd A, Elissa N, Donnelly MJ, Costa C, Gentile G, et al. Cooccurrence of East and West African kdr mutations suggests high levels of resistance to pyrethroid insecticides in Anopheles gambiae from Libreville, Gabon. Med Vet Ent. 2006;20:27-32.

38. Verhaeghen K, Van Bortel W, Roelants P, Backeljau T, Coosemans M. Detection of the East and West African kdr mutation in Anopheles gambiae and Anopheles arabiensis from Uganda using a new assay based on FRET/Melt Curve analysis. Malar J. 2006;5:16.

39. Namountougou M, Diabaté A, Etang J, Bass C, Sawadogo SP, Gnankinié $\mathrm{O}$, et al. First report of the L1014S kdr mutation in wild populations of Anopheles gambiae M and S molecular forms in Burkina Faso (West Africa). Acta Trop. 2013;125:123-7.

40. Chouaïbou M, Kouadio FB, Tia E, Djogbenou L. First report of the East African kdr mutation in an Anopheles gambiae mosquito in Côte d'Ivoire. Wellcome Open Res. 2017;2:8

41. Singh OP, Bali P, Hemingway J, Subbarao SK, Dash AP, Adak T. PCR-based methods for the detection of L1014 kdr mutation in Anopheles culicifacies sensu lato. Malar J. 2009;8:154.

42. Singh OP, Dykes CL, Das MK, Pradhan S, Bhatt RM, Agrawal OP, et al. Presence of two alternative kdr-like mutations, L1014F and L1014S, and a 
novel mutation, $\mathrm{V} 1010 \mathrm{~L}$, in the voltage gated $\mathrm{Na}+$ channel of Anopheles culicifacies from Orissa, India. Malar J. 2010;9:146.

43. Ahmad M, Buhler C, Pignatelli P, Ranson H, Nahzat SM, Naseem M, et al. Status of insecticide resistance in high-risk malaria provinces in Afghanistan. Malar J. 2016;15:98.

44. WHO. Malaria surveillance, monitoring \& evaluation: a reference manual. Geneva: World Health Organization; 2018.

45. WHO. Global malaria programme. Test procedures for insecticide resistance monitoring in malaria vector mosquitoes. 2nd ed. Geneva: World Health Organization; 2016.

46. WHO. Global plan for insecticide resistance management in malaria vectors (GPIRM). Geneva: World Health Organization; 2012.

47. Glick J. Illustrated key to the female Anopheles of Southwestern Asia and Egypt (Diptera: Culicidae). Mosq Syst. 1992;4:125-53.

48. Hemingway J. Field and laboratory manual for the mechanistic detection of insecticide resistance in insects. WHO-CTD/MAL/986. Geneva: World Health Organization; 1998. p. 35.

49. Livak KJ. Organization and mapping of a sequence on the Drosophila melanogaster $X$ and $Y$ chromosomes that is transcribed during spermatogenesis. Genetics. 1984;107:611-34.

50. Rodriguez S, Gaunt TR, Day IN. Hardy-Weinberg equilibrium testing of biological ascertainment for mendelian randomization studies. Am J Epidemiol. 2009;6:359.

51. Harris W. Agricultural developement for afghansitan, agricultural review of Kunar Province. Afghanistan; 2011. http://www.fresnostate.edu/jcast/ ifa/documents/pdf/adapt/KUNAR.pdf. Accessed 26 Dec 2018.

52. Afghanistan Research and Evaluation Unit. Provincial profiles: Regional Rural Economic Regeneration Assessment and Strategies (RRERS) study/ National Area Based Development Programme, Ministry of Rural Rehabilitation and Development (MRRD), GRM International; 2006.

53. Aïkpon R, Agossa F, Ossè R, Oussou O, Aïzoun N, Oké-Agbo F, et al. Bendiocarb resistance in Anopheles gambiae s.l. populations from Atacora department in Benin, West Africa: a threat for malaria vector control. Parasit Vectors. 2013;6:192.

54. Protopopoff N, Matowo J, Malima R, Kavishe R, Kaaya R, Wright A, et al. High level of resistance in the mosquito Anopheles gambiae to pyrethroid insecticides and reduced susceptibility to bendiocarb in north-western Tanzania. Malar J. 2013;12:149.

55. Edi CV, Djogbenou L, Jenkins AM, Regna K, Muskavitch MA, Poupardin $R$, et al. CYP6 P450 enzymes and ACE-1 duplication produce extreme and multiple insecticide resistance in the malaria mosquito Anopheles gambiae. PLoS Genet. 2014;10:e1004236.

56. Raghavendra K, Barik TK, Sharma P, Bhatt RM, Srivastava HC, Sreehari U, et al. Chlorfenapyr: a new insecticide with novel mode of action can control pyrethroid resistant malaria vectors. Malar J. 2011;10:16.

57. Bigoga JD, Ndangoh DN, Awono-Ambene PH, Patchoke S, Fondjo E, Leke RG. Pyrethroid resistance in Anopheles gambiae from the rubber cultivated area of Niete, South Region of Cameroon. Acta Trop. 2012;124:210-4

58. Fishel FM. IRAC's Insecticide mode of Action Classification. https://edis. ifas.ufl.edu/pdffiles/PI/PI12100.pdf. Accessed 26 Dec 2018.

59. Djègbè I, Agossa FR, Jones CM, Poupardin R, Cornelie S, Akogbéto M, et al. Molecular characterization of DDT resistance in Anopheles gambiae from Benin. Parasit Vectors. 2014;7:409.

60. Etang J, Manga L, Toto JC, Guillet P, Fondjo E, Chandre F. Spectrum of metabolic-based to DDT and pyrethroids in Anopheles gambiae s.l. populations from Cameroon. J Vector Ecol. 2007;32:123-33.

61. Fossog Tene B, Poupardin R, Costantini C, Awono-Ambene P, Wondji CS, Ranson $\mathrm{H}$, et al. Resistance to DDT in an urban setting: common mechanisms implicated in both $\mathrm{M}$ and $\mathrm{S}$ forms of Anopheles gambiae in the city of Yaoundé Cameroon. PLoS ONE. 2013:8:e61408.

62. Vontas JG, Small GJ, Hemingway J. Glutathione S-transferases as antioxidant defence agents confer pyrethroid resistance in Nilaparvata lugens. Biochem J. 2001;357:65-72.

63. Ketoh GK, Ahadji-Dabla KM, Chabi J, Amoudji AD, Apetogbo GY, Awokou $\mathrm{F}$, et al. Efficacy of two PBO long lasting insecticidal nets against natural populations of Anopheles gambiae s.l. in experimental huts, Kolokopé, Togo. PLOS ONE. 2018;13:e0192492.

64. Protopopoff N, Mosha JF, Lukole E, Charlwood JD, Wright A, Mwalimu $C D$, et al. Effectiveness of a long-lasting piperonyl butoxide-treated insecticidal net and indoor residual spray interventions, separately and together, against malaria transmitted by pyrethroid-resistant mosquitoes: a cluster, randomised controlled, two-by-two factorial design trial. Lancet. 2018:391:1577-88.

65. Cisse MBM, Keita C, Dicko A, Dengela D, Coleman J, Lucas B, et al. Characterizing the insecticide resistance of Anopheles gambiae in Mali. Malar J. 2015;14:327.

66. Assogba BS, Djogbénou LS, Saizonou J, Milesi P, Djossou L, Djegbe I, et al. Phenotypic effects of concomitant insensitive acetylcholinesterase (ace$1 \mathrm{R}$ ) and knockdown resistance ( $\mathrm{kdrR}$ ) in Anopheles gambiae: a hindrance for insecticide resistance management for malaria vector control. Parasit Vectors. 2014;7:548.

67. Nikpour F, Vatandoost H, Hanafi-Bojd AA, Raeisi A, Ranjbar M, Enayati AA, et al. Evaluation of deltamethrin in combination of piperonyl butoxide (PBO) against pyrethroid resistant malaria vector, Anopheles stephensi in IRS implementation: an experimental semi-filed trial in Iran. J Arthropodborne Dis. 2017;11:469-81.

68. Montella IR, Schama R, Valle D. The classification of esterases: an important gene family involved in insecticide resistance-A review. Mem Inst Oswaldo Cruz. 2012;107:437-49.

69. Penilla RP, Rodrigues AD, Hemingway J, Torres JL, Arredondo-Jimenez Jl, Rodriguez MH. Resistance management strategies in malaria vector mosquito control. Baseline data for a large-scale field trial against Anopheles albimanus in Mexico. Med Vet Ent. 1998;12:217-33.

70. Akiner MM. Malathion and propoxur resistance in Turkish populations of the Anopheles maculipennis Meigen (Diptera: Culicidae) and relation to the insensitive acetylcholinesterase. Turkiye Parazitol Derg. 2014;38:111.

71. Kabula B, Kisinza W, Tungu P, Ndege C, Batengana B, Kollo D, et al. Cooccurrence and distribution of East (L1014S) and West (L1014F) African knock-down resistance in Anopheles gambiae sensu lato population of Tanzania. Trop Med Int Health. 2014;19:331-41.

72. Protopopoff N, Verhaeghen K, Van Bortel W, Roelants P, Marcotty T, Baza D, et al. A significant increase in $k d r$ in Anopheles gambiae is associated with an intensive vector control intervention in Burundi highlands. Trop Med Int Health. 2008;13:1479-87.

73. Ndiath MO, Cailleau A, Orlandi-Pradines E, Bessell P, Pagès F, Trape JF, et al. Emerging knock-down resistance in Anopheles arabiensis populations of Dakar, Senegal: first evidence of a high prevalence of $k d r-e$ mutation in West African urban area. Malar J. 2015;14:364.

74. Nardini L, Hunt RH, Dahan-Moss YL, Christie N, Christian RN, Coetzee $\mathrm{M}$, et al. Malaria vectors in the Democratic Republic of the Congo: the mechanisms that confer insecticide resistance in Anopheles gambiae and Anopheles funestus. Malar J. 2017;16:448.

75. Chandre F, Darriet F, Duchon S, Finot L, Manguin S, Carnevale P, et al. Modifications of pyrethroid effects associated with $k d r$ mutation in Anophelos gambiae. Med Vet Ent. 2000;14:81-8.

76. Mathias DK, Ochomo E, Atieli F, Ombok M, Nabie Bayoh M, Olang G, et al. Spatial and temporal variation in the kdr allele L1014S in Anopheles gambiae s.s. and phenotypic variability in susceptibility to insecticides in Western Kenya. Malar J. 2011;10:10.

77. Mawejje HD, Wilding CS, Rippon EJ, Hughes A, Weetman D, Donnelly MJ. Insecticide resistance monitoring of field-collected Anopheles gambiae s.l. populations from Jinja, eastern Uganda, identifies high levels of pyrethroid resistance. Med Vet Ent. 2013:27:276-83.

78. Mint Mohamed Lemine A, Ould Lemrabott MA, Niang EHA, Basco LK, Bogreau $\mathrm{H}$, Faye $\mathrm{O}$, et al. Pyrethroid resistance in the major malaria vector Anopheles arabiensis in Nouakchott. Mauritania. Parasit Vectors. 2018:11:344.

79. Darriet F, Guillet P, Guessan RNN, Doannio JMC, Koffi AA, Konan LY, et al. The impact of permethrin and deltamethrin resistance in Anopheles gambiae s.s. on the efficacy of insecticide-treated mosquito nets. Geneva: World Health Organization; 1999; https://apps.who.int/iris/bitstream/ handle/10665/66463/WHO_MAL_99.1088.pdf?sequence=1\&isAll owed=y. Accessed 26 Dec 2018.

80. Darriet F, Guillet P, N'Guessan R, Doannio JM, Koffi A, Konan LY, et al. Impact of resistance of Anopheles gambiae ss to permethrin and deltamethrin on the efficacy of impregnated mosquito nets. Med Trop (Mars). 1998:58:349-54 (in French)

81. Darriet F, N'Guessan R, Koffi AA, Konan L, Doannio JM, Chandre F, et al. Impact of pyrethrin resistance on the efficacity of impregnated mosquito nets in the prevention of malaria: results of tests in experimental cases with deltamethrin SC. Bull Soc Pathol Exot. 2000;93:131-4 (in French). 
82. Darriet F, Robert V, Thovein N, Carnevalle P. Evaluation of the efficacy of permethrin-impregnated intact and perforated mosquito nets against vectors of malaria. Geneva: World Health Orgnization, WHO/ VBC/84:899.

83. Henry MC, Doannio JM, Darriet F, Nzeyimana I, Carnevale P. Efficacy of permethrin-impregnated Olyset Net mosquito nets in a zone with pyrethroid resistance vectors. II. Parasitic and clinical evaluation. Med Trop (Mars). 1999;59:355-7 (in French)

84. N'Guessan R, Corbel V, Akogbéto M, Rowland M. Reduced efficacy of insecticide-treated nets and indoor residual spraying for malaria control in pyrethroid resistance area, Benin. Emerg Infect Dis. 2007;13:199-206.

85. N'Guessan R, Darriet F, Doannio JM, Chandre F, Carnevale P. Olyset Net efficacy against pyrethroid-resistant Anopheles gambiae and Culex quinquefasciatus after 3 years'field use in C te d'Ivoire. Med Vet Entomol. 2001;15:97-104.
86. Strode C, Donegan S, Garner P, Enayati AA, Hemingway J. The Impact of pyrethroid resistance on the efficacy of insecticide-treated bed nets against African anopheline mosquitoes: systematic review and metaanalysis. PLoS Med. 2014;11:e1001619.

87. Enayati AA, Hemingway J. Pyrethroid insecticide resistance and treated bednets efficacy in malaria control. Pest Biochem Physiol. 2006;84:116-26.

88. Reimer L, Fondjo E, Patchoké S, Diallo B, Lee Y, Ng A, et al. Relationship between $k d r$ mutation and resistance to pyrethroid and DDT insecticides in natural populations of Anopheles gambiae. J Med Entomol. 2008;45:260-6.

\section{Publisher's Note}

Springer Nature remains neutral with regard to jurisdictional claims in published maps and institutional affiliations.
Ready to submit your research? Choose BMC and benefit from:

- fast, convenient online submission

- thorough peer review by experienced researchers in your field

- rapid publication on acceptance

- support for research data, including large and complex data types

- gold Open Access which fosters wider collaboration and increased citations

- maximum visibility for your research: over 100M website views per year

At BMC, research is always in progress.

Learn more biomedcentral.com/submissions 